\title{
Novel insights on use of doxorubicin to treat chemoresistant TNBC by Immunotherapy
}

Received: 12 June, 2020

Accepted: 17 July, 2020

Published: 18 July, 2020

*Corresponding author: Dr. Tze-chen Hsieh, Department of Biochemistry \& Molecular Biology, New York Medical College, Valhalla, New York 10595, USA, Tel: 914-594-4062; Fax: 914-594-4058;

Email: Tze-chen_Hsieh@NYMC.edu

https://www. peertechz.com

Check for updates

\section{Tze-Chen Hsieh* and Joseph M Wu}

Department of Biochemistry and Molecular Biology, New York Medical College, Valhalla, New York 10595, USA

Doxorubicin, a WHO listed essential medicine, is used primarily as a combination of taxane/ anthracycline (doxorubicin)/cyclophosphamide (TAC), for treating malignant diseases including triple-negative breast cancer (TNBC). TNBC is a subtype of breast cancer categorized by deficient estrogen receptor, progesterone receptor, and epidermal growth factor receptor HER-2 [1]. TNBC is challenging to treat due to its genotype and phenotype heterogeneity [2-5], aggressiveness, recurrence [6-10], and resistance to existing therapies. Roughly, $25-45 \%$ TNBC patients receiving TAC as preoperative therapy achieve complete response and excellent long-term prognosis [11], while patients who fail TAC have poor prognosis and few therapeutic choices [2]. Specifically, doxorubicin-responsive TNBC patients achieve disease-free status and superb longterm prognosis while non-responders face chemoresistance, metastasis, and limited post-doxorubicin options. To increase curable efficacy and counter drug resistance in TNBC, the discovery of clinically relevant, assayable targets and novel mechanism-based therapies are imperative. Unmet clinical needs that constitute the focus of this communication include: How can doxorubicin-response be improved and therapeutic targets be unraveled? What controls and counters the chemoresistance in treated subjects?

\section{PD-L1 expression and immune escape}

The immune checkpoint transmembrane protein, programmed cell death-ligand 1 (PD-L1) is expressed in a myriad of immune and tumor cells [12,13]. Tumor PD-L1 induces the demise of infiltrating cytotoxic T cells in the tumor environment by binding to receptor PD-1 on T cells $[13,14]$. As such, PD-L1 acts as a protective shield to counter the host immune surveillance mechanism. In certain cancer cell types, high expression of tumor cell PD-L1 correlates with clinical efficacy in the use of checkpoint blockade therapy where monoclonal antibodies are deployed to disrupt the PD-1/PD-L1 axis [15-20]. Disease- and progression-free survival to immune checkpoint blockade therapy has been shown in melanoma, lung, renal and breast carcinomas, in a small percentage of patients expressing high but not low/undetectable PD-L1 tumors [21-24].

Resistance to doxorubicin and metastasis in tumor cells is linked to the activation of PD-L1 [25]. PD-L1 in tumor cells regulates immunosuppression and tumor escape. An altered tumor immunity, drug resistance and increase in metastasis are among ways by which cancer cells elude chemotherapy $[26,27]$. We hypothesize that PD-L1 is a novel, cancer stageindependent marker to identify candidate cancer patients including TNBC who present clinical chemoresistance. Testing this hypothesis could help unravel existing gaps in treatment of TNBC, viz. tumor heterogeneity, lack of response to host immunity, and resistance to existing therapies. The outcome is significant because it probes the regulation of PD-L1 in doxorubicin-resistant tumor cells using TNBC as example, advances our knowledge of drug induced chemo- and -immune resistance via upregulation of tumor PD-L1, and facilitates the development of anti-PD-L1 approaches to prevent or treat cancer. We surmise that TNBC patients displaying doxorubicin resistance and metastasis may be amenable to treatment 
using the immune checkpoint blockade therapy to disrupt the interaction between PD1/PD-L1, thus offering a target-, stage- and cancer type-directed therapy for patients who fails chemotherapy. The efficacy to immune checkpoint inhibitors as gauged by disease-, progression-free survival has been shown in melanoma, lung, renal and breast carcinomas [2124].

\section{Novel regulation of PD-L1 by NF-KB, subject to modula- tion by NQ02}

The mechanism by which up regulation of PD-L1 alters response to host immunity in tumors, evident by resistance to treatment in patients has not been elucidate. Similarly, how PD-L1 in TNBC is regulated by doxorubicin remains unknown. In our published study, we show that at $\geq \mathrm{IC} 50$ resveratrol, a $\mathrm{NRH}$ :quinone oxidoreductase (NQO2) inhibitor increases PD-L1 in colon and breast cancer cells including TNBC by activation of nuclear factor-kappa B (NF- $\mathrm{B})$ (28). In EMT6 syngeneic breast tumor mouse model studies, we found that doxorubicin also induces PD-L1 [29]. We recently showed that in cancer cells treated with supra-pharmacological $\mathrm{NQO}_{2}$ inhibitor doxorubicin, a viable residual cell population remains and expresses greatly elevated PD-L1 accompanied by the activation of $\mathrm{NF}-\kappa \mathrm{B}$ and induction of DDR (DNA damage response) [29]. These observations suggest that in tumor cells, the acquisition of doxorubicin-resistance occurs in parallel with DDR- and $\mathrm{NF}-\kappa \mathrm{B}-$ mediated induction of PD-L1. As such, to improve the efficacy of doxorubicin, co-suppression of drug resistance and PD-L1 expression using anti-PD-L1 therapy seems a desirable, yet-to-be-explored therapeutic option. These observations are significant: $\mathrm{NF}-\kappa \mathrm{B}$ positively controls $\mathrm{PD}-\mathrm{L} 1$ while $\mathrm{NQO} 2$ is inversely associated with an increase in the risk of breast cancer. We hypothesize drug/treatment induced tumor PD-L1 may be associated with drug resistance. In addition, inhibitor of NQO2 can facilitates PD-L1-mediated tumor escape of host immunity and modulate doxorubicin-resistance via $\mathrm{NF}-\kappa \mathrm{B}$, provides gain-of-growth by treatment induced resistant tumor cells. It strongly suggests the use of anti-PD-L1-antibody - an underpinning of immune checkpoint inhibitors, as a therapeutic option for TNBC patients who fail the doxorubicin therapy. Tumor PD-L1 may serve as a drug-resistant biomarker and theranostic indicator for cancer patients e.g. TNBC. In addition, PD-L1 promotes tumor cell survival, and escape from host immunity, thus, immune checkpoint blockade therapy can appropriately treat chemoresistance mediated by drug e.g. doxorubicin induced tumor PD-L1 using combination versus single-agent therapy is illustrated (Figure 1). The underlying tenets are: (i) patients expressing low/no PD-L1 tumor cells are candidates for immune checkpoint-responsiveness, via the upregulation of $\mathrm{PD}-\mathrm{L} 1$, (ii) $\mathrm{NF}-\kappa \mathrm{B}$ signaling mediates the induction of PD-L1 as well as tumor survival, and (iii) the nonconventional phase II enzyme NQO2 characterized [30,31], plays the novel role of modulating $\mathrm{NF}-\kappa \mathrm{B}$ response/signaling to facilitate/enhance the elimination of tumor cells by host antitumor immunoregulatory processes.
Drugs: NQO2 inhibitors

(e.g. doxorubicin, resveratrol)

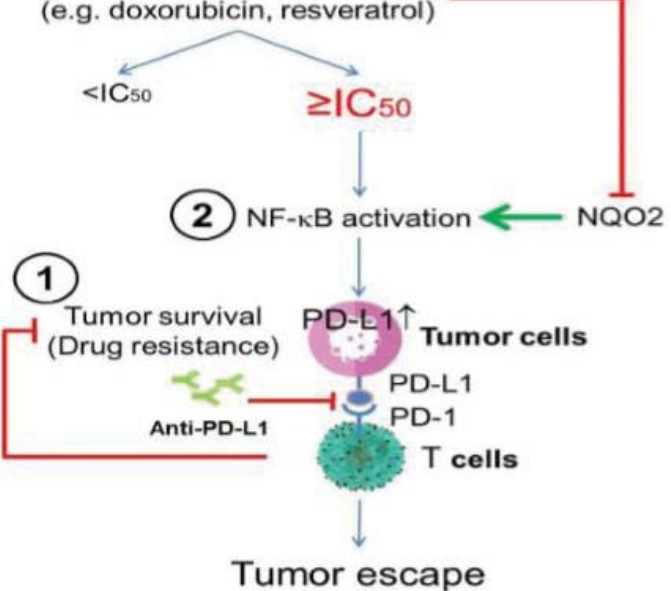

Figure 1: Schemes illustrate (1) drug induce upregulation of PD-L1 resulted drug resistance and tumor survival and (2) NQO2 mediates control of tumor PDL1, tumor cell survival/escape via NF-KB signaling. Tumor acquired resistance can become immune blockade-responsive by upregulating tumor PD-L1, with NF-KB as initiator, and NQO2 as the NF-KB mediator.

\section{References}

1. Hudis CA, Gianni L (2011) Triple-negative breast cancer: an unmet medical need. Oncologist 16: 1-11. Link: https://bit.ly/3ezXbQn

2. Liedtke C, Mazouni C, Hess KR, André F, Tordai A, et al. (2008) Response to neoadjuvant therapy and long-term survival in patients with triple-negative breast cancer. J Clin Oncol 26: 1275-1281. Link: https://bit.ly/2ClHajZ

3. Prat A, Parker JS, Karginova O, Fan C, Livasy C, et al. (2010) Phenotypic and molecular characterization of the claudin-low intrinsic subtype of breas cancer. Breast Cancer Res 12: R68. Link: https://bit.ly/2CNfog7

4. Masuda H, Baggerly KA, Wang Y, Gonzalez-Angulo AM, et al. (2013) Differential response to neoadjuvant chemotherapy among 7 triple-negative breast cancer molecular subtypes. Clin Cancer Res 19: 5533-5540. Link: https://bit.ly/2CGtoZg

5. Lehmann BD, Jovanović B, Chen X, Estrada MV, Johnson KN, et al. (2016) Refinement of Triple-Negative Breast Cancer Molecular Subtypes: Implications for Neoadjuvant Chemotherapy Selection. PLoS One 11: e0157368. Link: https://bit.ly/2WqzLHe

6. Dent R, Trudeau M, Pritchard KI, Hanna WM, Kahn HK, et al. (2007) Triplenegative breast cancer: clinical features and patterns of recurrence. Clin Cancer Res 13: 4429-4434. Link: https://bit.ly/2ZBE9oD

7. Schneider BP, Winer EP, Foulkes WD, Garber J, Perou CM, et al. (2008) Triplenegative breast cancer: risk factors to potential targets. Clin Cancer Res 14 8010-8018. Link: https://bit.ly/2ZzvcfC

8. De Laurentiis M, Cianniello D, Caputo R, Stanzione B, Arpino G, et al. (2010) Treatment of triple negative breast cancer (TNBC): current options and future perspectives. Cancer Treat Rev 36: S80-86. Link: https://bit.ly/3fB690U

9. Chacón RD, Costanzo MV (2010) Triple-negative breast cancer. Breast Cancer Res 12: S3. Link: https://bit.ly/2Ck9Bin

10. Tate CR, Rhodes LV, Segar HC, Driver JL, Pounder NF, et al. (2012) Targeting triple-negative breast cancer cells with the histone deacetylase inhibitor panobinostat. Breast Cancer Res 14: R79. Link: https://bit.ly/3jcugpf

11. Gonzalez-Angulo AM, McGuire SE, Buchholz TA, Tucker SL, Kuerer HM, et al. (2005) Factors predictive of distant metastases in patients with breast cancer 
who have a pathologic complete response after neoadjuvant chemotherapy. $J$ Clin Oncol 23: 7098-7104. Link: https://bit.ly/2DRLCaN

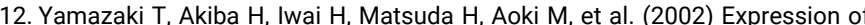
programmed death 1 ligands by murine T cells and APC. J Immunol 169: 5538 5545. Link: https://bit.ly/2Zzw9oc

13. Dong H, Strome SE, Salomao DR, Tamura H, Hirano F, et al. (2002) Tumorassociated $\mathrm{B} 7-\mathrm{H} 1$ promotes T-cell apoptosis: a potential mechanism of immune evasion. Nat Med 8: 793-800. Link: https://bit.ly/2ZBv27v

14. Hanahan D, Weinberg RA (2011) Hallmarks of cancer: the next generation. Cell 144: 646-674. Link: https://bit.ly/3h7U3wP

15. Akbay EA, Koyama S, Carretero J, Altabef A, et al. (2013) Activation of the PD-1 pathway contributes to immune escape in EGFR-driven lung tumors. Cancer Discov 3: 1355-1363. Link: https://bit.ly/30ismeb

16. Mittal D, Gubin MM, Schreiber RD, Smyth MJ (2014) New insights into cance immunoediting and its three component phases--elimination, equilibrium and escape. Curr Opin Immunol 27: 16-25. Link: https://bit.ly/32p93Cw

17. Lyford-Pike S, Peng S, Young GD, Taube JM, Westra WH, et al. (2013) Evidence for a role of the PD-1:PD-L1 pathway in immune resistance of HPV-associated head and neck squamous cell carcinoma. Cancer Res 73: 1733-1741. Link: https://bit.ly/2CclfvT

18. He J, Hu Y, Hu M, Li B (2015) Development of PD-1/PD-L1 Pathway in Tumo Immune Microenvironment and Treatment for Non-Small Cell Lung Cancer Sci Rep 5: 13110. Link: https://go.nature.com/30ijZzg

19. Noh H, Hu J, Wang X, Xia X, Satelli A, et al. (2015) Immune checkpoint regulator PD-L1 expression on tumor cells by contacting CD11b positive bone marrow derived stromal cells. Cell Commun Signal 13: 14. Link: https://bit.ly/30iE4W1

20. Kim JM, Chen DS (2016) Immune escape to PD-L1/PD-1 blockade: seven steps to success (or failure). Ann Oncol 27: 1492-1504. Link: https://bit.ly/2WuoFAW

21. Topalian SL, Hodi FS, Brahmer JR, Gettinger SN, Smith DC, et al. (2012) Safety, activity, and immune correlates of anti-PD-1 antibody in cancer. N Engl J Med 366: 2443-2454. Link: https://bit.ly/30q6Nbl

22. Topalian SL, Sznol M, McDermott DF, Kluger HM, Carvajal RD, et al. (2014) Survival, durable tumor remission, and long-term safety in patients with advanced melanoma receiving nivolumab. J Clin Oncol 32: 1020-1030. Link: https://bit.ly/2Ccm0Ff

23. Hamid O, Robert C, Daud A, Hodi S, Hwu WJ, et al. (2013) Safety and tumor responses with lambrolizumab (anti-PD-1) in melanoma. N Engl J Med 369 134-144. Link: https://bit.ly/2ZAROHw

24. Gadiot J, Hooijkaas Al, Kaiser AD, van Tinteren $\mathrm{H}$, van Boven $\mathrm{H}$, et al. (2011) Overall survival and PD-L1 expression in metastasized malignant melanoma. Cancer 117: 2192-2201. Link: https://bit.ly/2B6SRKS

25. Black M, Barsoum IB, Truesdell P, Cotechini T, Macdonald-Goodfellow SK, et al. (2016) Activation of the PD-1/PD-L1 immune checkpoint confers tumor cell chemoresistance associated with increased metastasis. Oncotarget 7: 1055710567. Link: https://bit.ly/2B5qyfM

26. Loi S, Pommey S, Haibe-Kains B, Beavis PA, Darcy PK, et al. (2013) CD73 promotes anthracycline resistance and poor prognosis in triple negative breast cancer. Proc Natl Acad Sci U S A 110: 11091-11096. Link: https://bit.ly/2ZCQARi

27. Kim JE, Jang MJ, Jin DH, Chung YH, Choi BS, et al. (2014) Paclitaxel-exposed ovarian cancer cells induce cancer-specific CD4+ $\mathrm{T}$ cells after doxorubicin exposure through regulation of MyD88 expression. Int J Oncol 44: 1716-1726. Link: https://bit.ly/3jfDsJl

28. Lucas J, Hsieh TC, Halicka HD, Darzynkiewicz Z, Wu JM (2018) Upregulation of PD-L1 expression by resveratrol and piceatannol in breast and colorectal cancer cells occurs via HDAC3/p300-mediated NF-kB signaling. Int J Oncol 53: 1469-1480. Link: https://bit.ly/2Zzr6Ei

29. Lucas J (2018) Immune Regulation of the Tumor Microenvironment by EZH2: Epigenetic Priming for Immune Oncology Combinations. Ph.D. dissertation. New York Medical College, New York, U.S.A.

30. Ahn KS, Gong X, Sethi G, Chaturvedi MM, Jaiswal AK, et al. (2007) Deficiency of $\mathrm{NRH}$ :quinone oxidoreductase 2 differentially regulates TNF signaling in keratinocytes: up-regulation of apoptosis correlates with down-regulation of cell survival kinases. Cancer Res 67: 10004-10011. Link: https://bit.ly/3jaN8F9

31. Hsieh TC (2009) Antiproliferative effects of resveratrol and the mediating role of resveratrol targeting protein NQO2 in androgen receptor-positive, hormonenon-responsive CWR22Rv1 cells. Anticancer Res 29: 3011-3017. Link: https://bit.ly/2OLeELz

\section{Discover a bigger Impact and Visibility of your article publication with}

Peertechz Publications

\section{Highlights}

* Signatory publisher of ORCID

* Signatory Publisher of DORA (San Francisco Declaration on Research Assessment)

* Articles archived in worlds' renowned service providers such as Portico, CNKI, AGRIS, TDNet, Base (Bielefeld University Library), CrossRef, Scilit, J-Gate etc.

* Journals indexed in ICMJE, SHERPA/ROMEO, Google Scholar etc.

* OAI-PMH (Open Archives Initiative Protocol for Metadata Harvesting)

- Dedicated Editorial Board for every journal

* Accurate and rapid peer-review process

* Increased citations of published articles through promotions

* Reduced timeline for article publication

Submit your articles and experience a new surge in publication services (https://www.peertechz.com/submission).

Peertechz journals wishes everlasting success in your every endeavours.

Copyright: @ $) 2020$ Hsieh TC, et al. This is an open-access article distributed under the terms of the Creative Commons Attribution License, which permits unrestricted use, distribution, and reproduction in any medium, provided the original author and source are credited.

Citation: Hsieh TC, Wu JM (2020) Novel insights on use of doxorubicin to treat chemoresistant TNBC by Immunotherapy. Int J Immunother Cancer Res 6(1): 016-018 DOI: https://dx.doi.org/10.17352/2455-8591.000024 